\title{
The Effect of Boriding and Heat Treatment on the Structure and Properties of 100Cr6 Steel
}

David Bricín (0000-0002-9354-2751)1, Antonín Kř́ǐz (0000-0001-8188-6621)², Jan Novotný (0000-0001-76768495) $)^{2}$, Zbyněk Špirit (0000-0002-5676-1840)3

${ }^{1}$ Department of Material Science and Technology, Faculty of Mechanical Engineering, University of West Bohemia in Pilsen. Univerzitní 8, 30100 Plzen. Czech Republic. E-mail: bricda@kmm.zcu.cz ${ }^{1 *}$, kriz@kmm.zcu.cz²

${ }^{2}$ Faculty of Mechanical Engineering, J. E. Purkyne University in Usti nad Labem. Pasteurova 3334/7, 40001 Usti nad Labem. Czech Republic. E-mail: jan.novotny@ujep.cz

${ }^{3}$ Centrum výzkumu Rez s.r.o., Morseova 1245/6, 301 00, Pilsen, Czech Republic

The main aim of this case study is to present the changes caused by heat treatment on the structure and properties of $100 \mathrm{Cr} 6$ steel by annealing, hardening, and tempering in combination with previous chemical-heat treatment (CHT) by boriding. The boriding causes changes to the microstructure of the steel samples, which include a change in the morphology of the deposited cementite and a change in the volume of the chromium carbide particles. The cementite is transformed from its original granular form to a lamellar form. An increase in the proportion of chromium carbide particles in the sample occurs due to the higher affinity of chromium for carbon. This leads to precipitation of chromium carbides rather than carbides of iron. A multiphase diffusion layer $\mathrm{Fe}_{2} \mathrm{~B}-\mathrm{FeB}$ with a thickness of $31 \pm 2.8 \mu \mathrm{m}$ is formed during boriding, with a typical tooth-like texture. Although the diffusion layer does not have the same toughness and resistance as the single-phase $\mathrm{Fe}_{2} \mathrm{~B}$ diffusion layer, samples after boriding increase their resistance to tribological abrasion by $29 \%$ compared to samples without this treatment. After quenching and tempering of the borided samples, a maximum tensile strength of $\mathrm{Rm}=1779 \mathrm{MPa}$ is measured. Compared to samples which are only quenched and subsequently tempered, this is an increase in tensile strength of about $59 \%$.

Keywords: $100 \mathrm{Cr} 6$, boriding, heat treatment, hardening, tempering, annealing

\section{Introduction}

$100 \mathrm{Cr} 6$ steel is commonly used to make the rolling elements for various types of bearings [1]. Emphasis is placed on achieving the high hardness and abrasion resistance of these elements, which are two basic prerequisites for their long service life. These properties are attained via the steel's chemical composition and heat treatment by hardening, which is usually followed by tempering. When quenching, it is necessary to cool the material from the austenitization temperature fast enough to suppress the formation of equilibrium structures, such as pearlite. This ensures that the resulting structure is formed from non-equilibrium structures, including martensite, see Fig. 1. In addition to the cooling rate, the final structure and hardness of the steel after heat treatment are significantly dependent on the initial chemical composition. The chemical composition of the steel affects the phases that occur during heat treatment and affects the temperatures and times at which these phases arise or disappear. The influence of various elements on the shape of the
100Cr6 steel diagram is shown in Fig. 1. Other factors that affect the final structure of the steel after heat treatment include the level of the hardening (austenitization) temperature, the grain size of the austenite, introduced deformation, and, last but not least, the structure of the steel before heat treatment [2-3]. The resulting abrasion resistance of the material can then be further increased by surface treatment. Inexpensive treatments include boriding technologies which form either a single-phase $\mathrm{Fe}_{2} \mathrm{~B}$ layer or a multiphase $\mathrm{FeB}$ $\mathrm{Fe}_{2} \mathrm{~B}$ layer on the steel surface. A multiphase layer is less advantageous in terms of its potential applications because $\mathrm{FeB}$ boride is less tough than $\mathrm{Fe}_{2} \mathrm{~B}$ boride. One of the advantages of boriding is that the degradation of the diffusion layer, its melting, only occurs at temperatures above $1050{ }^{\circ} \mathrm{C}[5]$. This allows the products to be further heat-treated after boriding. In addition, the layer has a high hardness (700-3370 HV) and a low coefficient of friction [6]. The main goal of this study is to verify how the boride diffusion layer affects the properties of $100 \mathrm{Cr} 6$ steel and how these proper- 
ties differ from processing by conventional heat treatment using hardening and tempering. The results were further compared with the properties of samples which had been processed for a long time - annealed in a furnace without a protective atmosphere under the same process conditions as the borided samples.
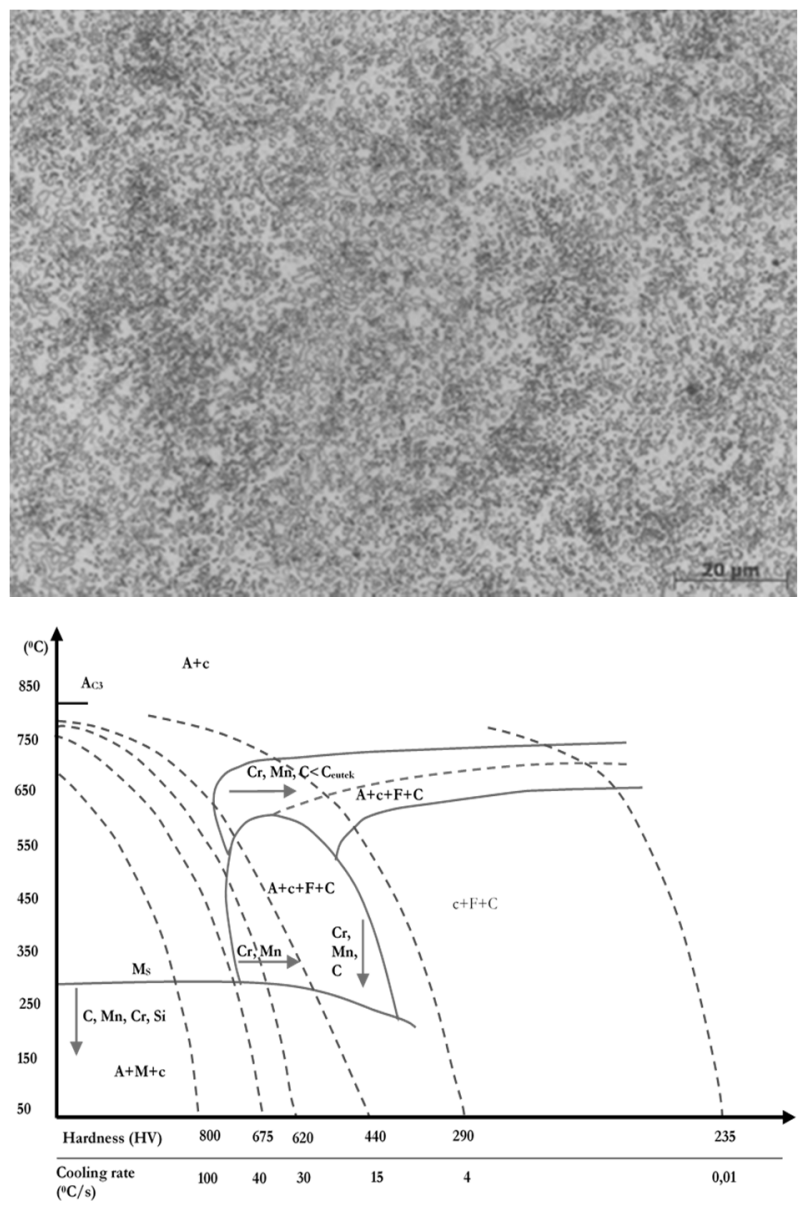

\section{Experimental parameters}

The experimental material was a $100 \mathrm{Cr} 6$ steel bar in the soft annealed state with a diameter of $30 \mathrm{~mm}$. In this state, its structure is formed by granular pearlite and chromium carbides in a ferritic matrix, see Fig. 2a. The chemical composition is given in Table 1. Different types of samples were made from the bar depending on the experiments. Samples with a nominal height of $15 \mathrm{~mm}$ were created for metallographic analysis and analysis of the surface properties of the material. The surface of the samples was ground with an MD-Piano 500 grinding wheel before further processing so that a similar roughness was achieved on the surfaces of all the samples. The second type of sample was a test bar used to determine the tensile strength of the material. The shape and dimensions of the bars were in accordance with the standard ČSN EN ISO 6892-1 [7]. After creating the samples, they were divided into groups, see Table 1. The first group was processed in the conventional manner. Some of the samples underwent
The aim of this step was to determine how the microstructure and properties of $100 \mathrm{Cr} 6$ steel are affected by its long-term exposure to high temperatures, and how its properties then differ from the properties of samples processed by the other methods.

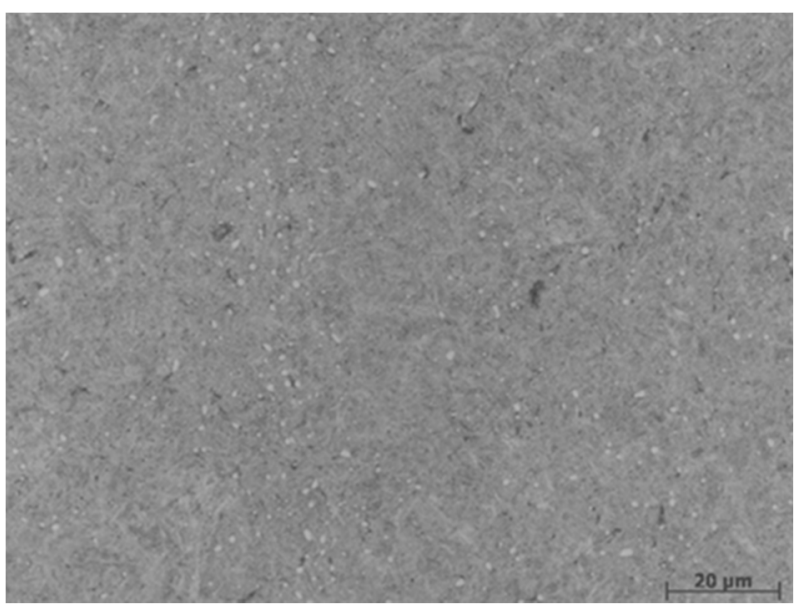

Fig. 1 ARA Diagram of 100Cr6 steel and comparison of its microstructure obtained by different forms of heat treatment [34]. The photograph on the left shows the structure of the experimental material after soft annealing, where the structure consists of granular pearlite and carbides in a ferritic matrix. This structure was formed by gradual heating, sufficiently long holding at the annealing temperature, and gradual slow cooling of the steel structure in the furnace. The photograph on the right shows the structure after the quenching. The cooling rate was large enough to form an unbalanced martensite structure, in this case, water was used as the cooling medium. The resulting structure consists of martensite, residual austenite, and carbides

hardening and others were further tempered after hardening. The second group was thermochemically treated in Durborit boriding powder before the heat treatment. The last group was treated in a chamber furnace at the same temperature and for the same time as the borided samples. After heat treatment the samples were analysed to determine the differences in their structure and properties.

The analyses of the samples included metallographic analysis. This was performed on transverse metallo-graphic sections after chemical etching using $3 \%$ Nital etchant solution. Metallographic images were taken using a CarlZeiss Observer Z1m optical microscope and a PHILIPS XL30ESEM scanning electron micro-scope (SEM). Using SEM, we carried out a local points EDX analysis of the chemical composition of the analysed samples. Metallographic analysis was supplemented by microhardness analysis of the samples using the HV0.1 method. We used a DuraScan semi-automatic hardness tester. Microhardness was measured on each sample to a distance of $1 \mathrm{~mm}$ 
from the surface. The distance between the impressions was $0.1 \mathrm{~mm}$. Tensile strength was measured at room temperature using a Zwick Roell Z250 test system. A Ball-on Disc test was performed to analyse the tribological properties of the sample surface. The worn volume of material was determined according to the ASTM-G99 standard. The test parameters were: tribological track radius $\mathrm{r}=3 \mathrm{~mm}$, load $\mathrm{Fn}=30 \mathrm{~N}$, speed $154 \mathrm{rpm}$, number of repetition cycles 5,000. The indenter was a $3 \mathrm{~mm}$ radius sapphire ball. The wear coefficient was then calculated according to Equation 1 below [8].

$$
W=\frac{V}{L \cdot s}\left[\mathrm{~mm}^{3} / \mathrm{N} \cdot \mathrm{m}\right]
$$

Where:

V... Wear volume $\left[\mathrm{mm}^{3}\right]$,

L... Normal load Fn $[\mathrm{N}]$,

s... Total test distance $[\mathrm{m}]$.

Tab. 1 Chemical composition of $100 \mathrm{Cr} 6$ steel structure measured by EDAX analyser, and the methodology of heat treatments of the samples

\begin{tabular}{|c|c|c|c|c|c|c|}
\hline Element & $\mathrm{Cr}$ & \multicolumn{2}{|c|}{$\mathrm{Mn}$} & \multicolumn{2}{|c|}{$\mathrm{Si}$} & $\mathrm{Fe}$ \\
\hline (Wt. \%) & $2.4 \pm 0.13$ & \multicolumn{2}{|c|}{$1.5 \pm 0.03$} & \multicolumn{2}{|c|}{$0.2 \pm 0.23$} & rest \\
\hline $\begin{array}{c}\text { Processing } \\
\text { type }\end{array}$ & \multicolumn{3}{|c|}{ boriding } & \multicolumn{3}{|c|}{ annealing } \\
\hline $\begin{array}{l}\text { Series of } \\
\text { samples }\end{array}$ & $\begin{array}{c}\text { Temperature } \\
\left({ }^{\circ} \mathrm{C}\right)\end{array}$ & $\begin{array}{l}\text { Holding time } \\
\text { (hour) }\end{array}$ & $\begin{array}{l}\text { cooling environ- } \\
\text { ment }\end{array}$ & $\begin{array}{c}\text { Temperature } \\
\left({ }^{\circ} \mathrm{C}\right)\end{array}$ & $\begin{array}{l}\text { Holding time } \\
\text { (hour) }\end{array}$ & $\begin{array}{l}\text { cooling environ- } \\
\text { ment }\end{array}$ \\
\hline 1 & - & - & - & - & - & - \\
\hline 2 & 840 & 6 & furnace & - & - & - \\
\hline 3 & - & - & - & 840 & 6 & furnace \\
\hline 4 & 840 & 6 & furnace & - & - & - \\
\hline 5 & - & - & - & 840 & 6 & furnace \\
\hline 6 & - & - & - & - & - & - \\
\hline 7 & & & & 840 & 6 & furnace \\
\hline 8 & 840 & 6 & furnace & - & - & - \\
\hline 9 & - & - & - & - & - & - \\
\hline $\begin{array}{c}\text { Processing } \\
\text { type }\end{array}$ & \multicolumn{3}{|c|}{ hardening } & \multicolumn{3}{|c|}{ tempering } \\
\hline $\begin{array}{l}\text { Series of } \\
\text { samples }\end{array}$ & $\begin{array}{c}\text { Temperature } \\
\left({ }^{\circ} \mathrm{C}\right)\end{array}$ & $\begin{array}{l}\text { Holding time } \\
\text { (hour) }\end{array}$ & $\begin{array}{c}\text { cooling environ- } \\
\text { ment }\end{array}$ & $\begin{array}{c}\text { Temperature } \\
\left({ }^{\circ} \mathrm{C}\right)\end{array}$ & $\begin{array}{l}\text { Holding time } \\
\text { (hour) }\end{array}$ & $\begin{array}{l}\text { cooling environ- } \\
\text { ment }\end{array}$ \\
\hline 1 & - & - & - & - & - & - \\
\hline 2 & - & - & - & - & - & - \\
\hline 3 & - & - & - & - & - & - \\
\hline 4 & 850 & 3 & oil & 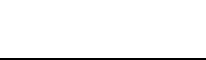 & 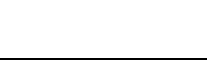 & . \\
\hline 5 & 850 & 3 & oil & - & - & - \\
\hline 6 & 850 & 3 & oil & - & - & - \\
\hline 7 & 850 & 3 & oil & 200 & 2 & furnace \\
\hline 8 & 850 & 3 & oil & 200 & 2 & furnace \\
\hline 9 & 850 & 3 & oil & 200 & 2 & furnace \\
\hline
\end{tabular}

\section{Experimental results}

Various phase transformations occurred in the structure of $100 \mathrm{Cr} 6$ steel as a result of the heat treatment, see Fig. 2. The initial structure consisting of granular pearlite and chromium carbides Fig. 2a was gradually heated above the AC3 temperature in the first phase of the heat treatment. At this temperature, the steel structure gradually transforms into austenite. The formation of austenitic nuclei occurs first at the interface between cementite and ferrite. The resulting 
austenitic nuclei are gradually saturated with carbon, whose solubility in austenite increases with temperature. The ferrite and subsequently the cementite are gradually transformed into austenite. However, the austenite obtained in the first phase of austenitization does not have a uniform chemical composition even after the cementite has dissolved. In areas where cementite particles were found, the carbon content remains higher. In addition, the structure also contains undissolved chromium carbides. The time taken for the homogenization of the austenite structure is highly dependent on the austenitization temperature and also on the rate of heating to this temperature [9-10].
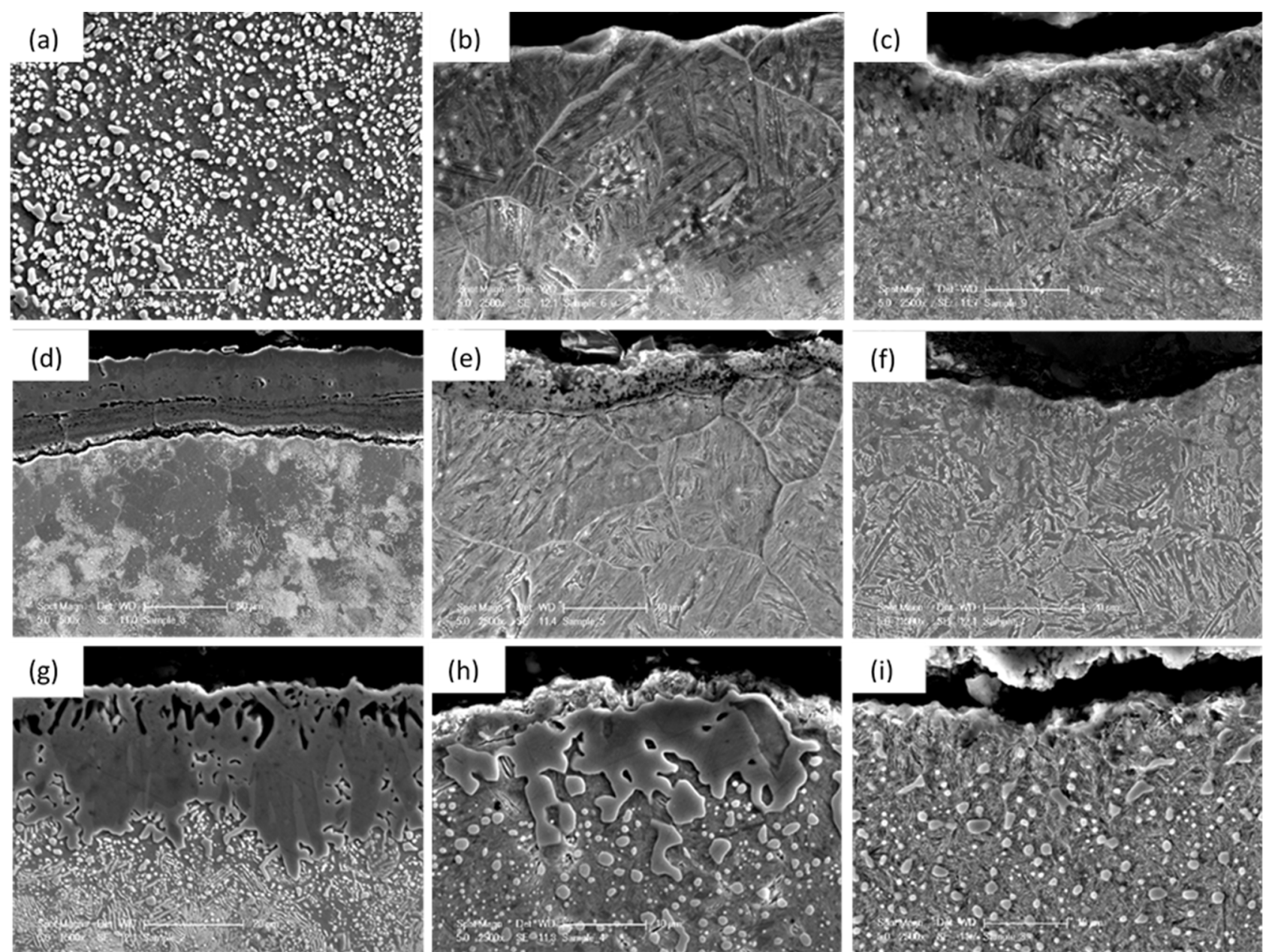

Fig. 2 Microstructure of the surface of the samples. (a) - initial structure, (b) - initial structure after hardening, (c) - initial structure after hardening and tempering, (d) - structure after long-term annealing, (e) - hardened structure after long-term annealing, (f) - tempered structure after hardening and long-term annealing, (g) - structure after boriding, (b) - bardening structure after boriding, (i) -

tempered structure after hardening and long-term annealing

Sample surfaces that were annealed for a long time during austenitization Fig. $2 d$ or borided Fig. $2 g$ interacted with the surrounding environment resulting in different types of diffusion layers forming on their sur-faces. An oxide diffusion layer with a thickness of $49 \pm 8.5 \mu \mathrm{m}$ formed on the samples which were annealed at $840^{\circ} \mathrm{C}$ for six hours. Below this layer, there was an area of decarburization with a depth of $93 \pm$ $18 \mu \mathrm{m}$. In this area, EDX analysis revealed a decrease in the proportion of chromium of about $32 \mathrm{wt} . \%$ of its original value. The formation of this decarburized region depleted of carbon and chromium meant that during cooling there was no re-precipitation of carbides in this area, which led to a reduction in the hardness of the surface layer, see Fig. 3a. In contrast, the borided samples Fig. $2 \mathrm{~g}$ formed a multiphase porous layer $\mathrm{FeB}-\mathrm{Fe}_{2} \mathrm{~B}$ with a thickness of $31 \pm 2.8 \mu \mathrm{m}$. This multiphase layer is disadvantageous in terms of further processing due to the layers' different coefficients of thermal expansion, different crystallographic structures and the difference in the residual stresses that these phases create on the surface of the treated material $[6,11-12]$. Unlike the $\mathrm{Fe}_{2} \mathrm{~B}$ phase, the $\mathrm{FeB}$ phase introduces tensile residual stresses into the surface, which then allows easier propagation of cracks from the surface of the material during further processing or loading [6]. However, the presence of a boride layer prevented the formation of a decarburized region. As a result, the carbide phases in the region below the diffusion layer were re-precipitated on cooling from the 
austenitizing temperature. Because the cooling rate gradient was high enough in this case, cementite was precipitated into a lamellar structure. This then led to an increase in the hardness of the sample matrix after the boriding process, see Fig. 3a. During the subsequent heat treatment of the samples by hardening, see Figs. $2 \mathrm{~b}, 2 \mathrm{e}$ and $2 \mathrm{~h}$, an unbalanced structure of martensite was formed during cooling from the austenitization temperature. The hardness of this structure, see Fig. 3b, then depended on the degree of decarburization of the surface, which also occurred during the hardening process. During the tempering process, the metastable structure of mar-tensite gradually disintegrated, see Figs. 2c, 2f and 2i, and the associated residual stresses in the surface layer of the analysed samples also decreased. This then led to a reduction in the microhardness of the surface of the samples relative to their hardened state, see Fig. 3c.

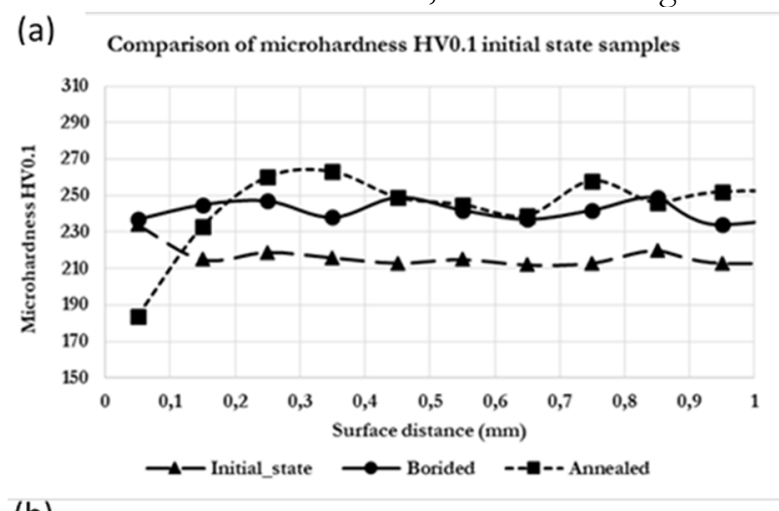

(b) Comparison of microhardness HV0.1 quenched samples
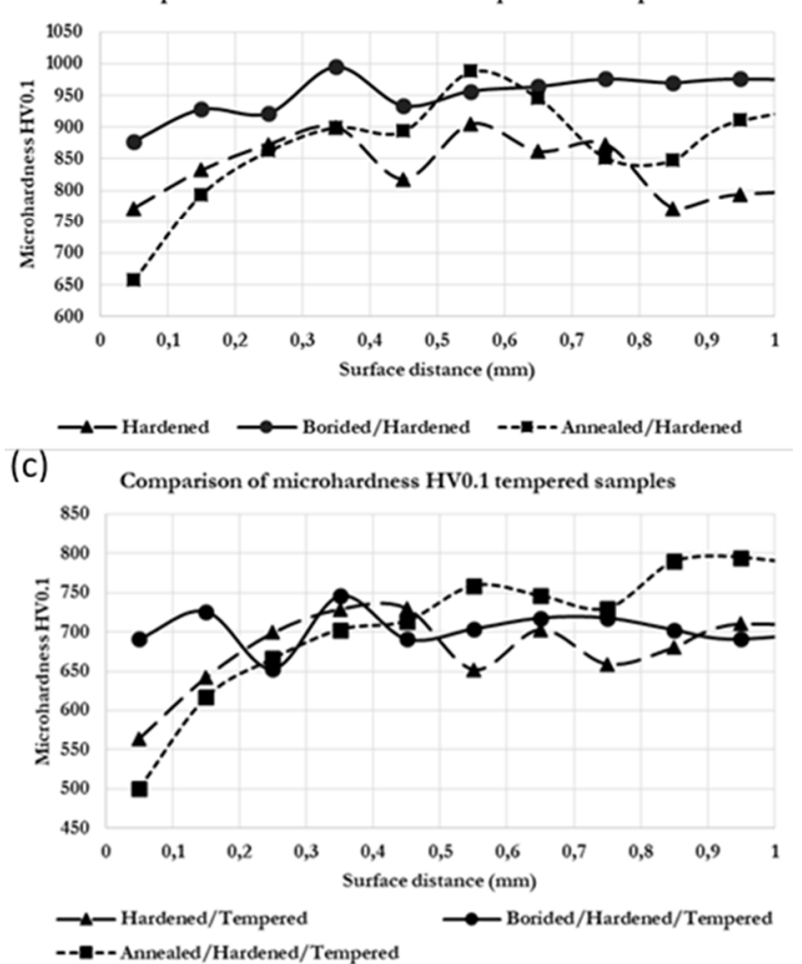

--n---Annealed/Hardened/Tempered

Fig. 3 Comparison of microhardness HVO.1 of the samples. (a) - microhardness in the initial state. (b) - microhardness after bardening. (c) - microhardness of samples that have been tempered after bardening of their structure
The changes in the sample microstructures due to different heat treatments led to different tribological be-haviours, see Fig. 4, and different tensile strengths, see Fig. 5. A comparison of the calculated wear coefficient $\mathrm{W}$ shows that boriding of $100 \mathrm{Cr} 6$ samples increases surface resistance by about $29 \%$. In contrast, long-term annealed samples had a reduced resistance of about $214 \%$. The reduction in the strength of the matrix of samples treated in this way was due to decarburization of the surface during heat treatment. In contrast, after hardening, the borided samples showed the highest value of wear coefficient, i.e. the lowest value of resistance to tribological abrasion. The fact that there was such a significant deterioration in the abrasion properties of the borided material after hardening was connected with the formation of a porous two-phase diffusion layer $\mathrm{FeB}-\mathrm{Fe}_{2} \mathrm{~B}$, which increased the brittleness of the sample surface. As mentioned above, during boriding, the carbides gradually dissolved at the process temperature and were subsequently re-precipitated to form a lamellar pearlite structure consisting of alpha ferrite and cementite. However, in addition to pearlite, a substantial part of the structure of this steel after boriding was formed by chromium carbides. These carbides were formed during the boriding process because chromium has a higher affinity for carbon than iron. This means that chromium carbides are formed preferentially and their proportion increases in the matrix of $100 \mathrm{Cr} 6$ steel samples [13]. Chromium carbides have greater thermal stability than iron carbides. This meant that the chromium and car-bon, which would normally dissolve in a solid solution of gamma iron and subsequently contribute to the formation of a martensitic structure, remained bound in the form of carbides. Since these carbides are torn out of the matrix of the material during the movement of an invasive body, their presence is one of the reasons why the wear coefficient of the structure of the material increases. The highest resistance to tribological abrasion was shown by the samples after hardening without prior treatment. After subsequent tempering, the abrasion resistance increased again, both for the borided samples and for the samples which were only hard-ened before tempering. One reason for this in the borided samples was probably the equalization of the micro-stresses acting in the surface layer of the samples. This may be related to the reduction of the difference in boron concentration at the interface between the structural phases of the $\mathrm{FeB}-\mathrm{Fe}_{2} \mathrm{~B}$ diffusion layer. For the formation of the $\mathrm{Fe}_{2} \mathrm{~B}$ phase, a lower concentration of boron is needed, about 33 at. \% [6]. For the formation of the structural phase of $\mathrm{FeB}$, it is then necessary to increase the concentration of boron to a value of about 50 at. 
$\%$ [6]. During tempering, due to diffusion phenomena, the concentration differences in the boron content in the diffusion layer are compensated, and thus the structurally more brittle $\mathrm{FeB}$ phase can gradually disappear. The higher resistance of hardened and subsequently tempered samples is then associated with a higher degree of supersaturation of the solid solution $\alpha^{\prime}$, i.e. martensite with carbon, which was less bound in the form of more stable chromium carbides than the samples tempered after boriding. Because the tempering process took place at a temperature of $200{ }^{\circ} \mathrm{C}$, the structure of martensite disintegrated into cubic tempered marten-site, which consists of low-carbon martensite and carbide $\varepsilon$ [14]. In the long-term annealed samples, the tempering effect did not manifest itself so much because the surface layer was significantly depleted of carbon during the previous processing and thus there was no significant supersaturation of the solid solution, which was reflected in the deterioration of the tribological abrasion re-sistance of the material surface.

For an evaluation of the changes in the tensile strength of $100 \mathrm{Cr} 6$ samples of steel, see Fig. 5. The samples after the boriding process and the samples after the annealing process have a higher tensile strength than the samples without heat treatment. This fact is again associated with the previously described microstructural changes, which include a change in the morphology of the cementite and an increase in the proportion of chromium carbides in the matrix of this steel. Surface decarburization then manifested itself in a slight increase in the value of the yield strength $\mathrm{R}_{\mathrm{p} 0.2}$ by about $2.3 \%$, compared to the samples that were borided. The de-carburization depth and the thickness of the boride layer did not significantly affect the tensile strength of $\mathrm{R}_{\mathrm{M}}$. This was because similar diffusion processes took place in the remaining volume of the sample material, which was significantly larger, and led to the formation of a similar microstructure. The presence of diffusion layers on the surface of the samples after annealing and boriding became apparent during the hardening of the structure of the material. The presence of cracks was recorded in the structure of the annealed samples. These cracks progressed along the boundaries of the original austenitic grains into the volume of the material. Their presence is associated with the weakening of the material's grain boundaries, which occurred due to the progressive oxidative attack of the structure of $100 \mathrm{Cr} 6$ samples of steel during long-term annealing. This then brought about a significant reduction in the tensile strength of its structure. The borided samples then showed the effect of their different initial microstructure compared to the only hardened samples. For the only hardened samples, it was possible to saturate a higher proportion of carbon in the tetragonal structure of the martensite. As a result, greater structural stresses acted in these samples, which led to earlier failure than the borided samples. There was a further increase in tensile strength during subsequent tempering when the highest values were reached by the borided samples $\left(\mathrm{R}_{\mathrm{M}}=1779 \mathrm{MPa}\right)$. Compared to hardened and subsequently tempered samples, this is an increase in tensile strength of about $59 \%$. The increase in tensile strength after tempering is associated with a change in the morphology of the precipitated martensite and a decrease in the stresses acting in the structure of the samples.

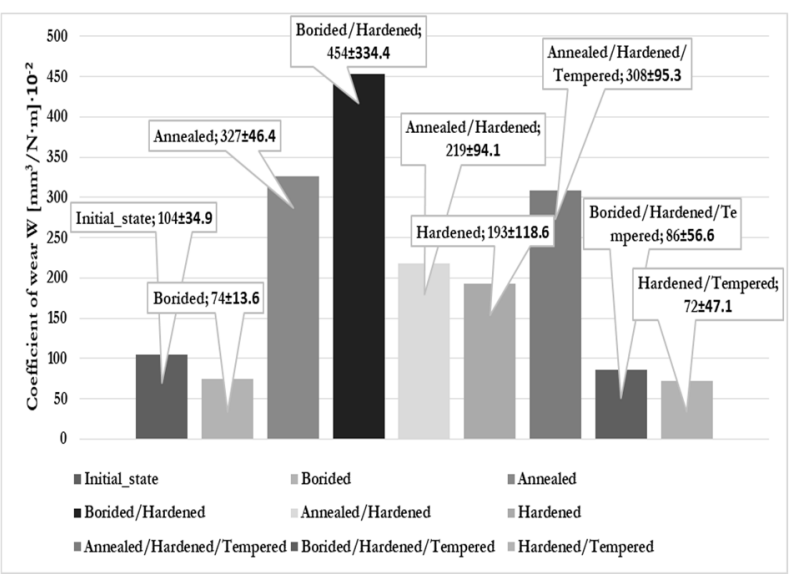

Fig. 4 Comparison of values of wear coefficient $W$ for different heat-treated samples

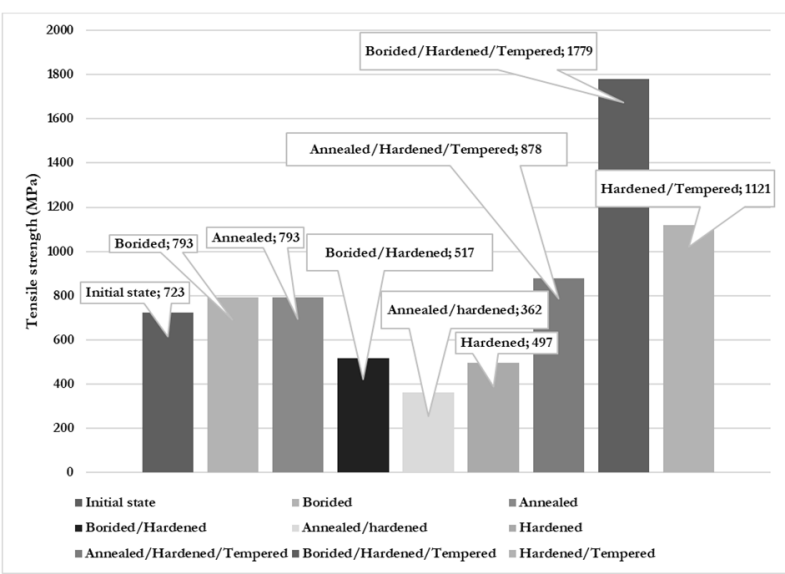

Fig. 5 Comparison of tensile strength values $\mathrm{R} m$ for heat-treated samples

The highest degree of plastic deformation was measured for samples in the ground state and samples after boriding and annealing. No significant plastic deformation was observed in the fracture area of the samples after hardening and tempering. In addition to deformations near the fracture, there was a change in the morphology of the fracture surfaces due to the change in the microstructure, see Fig. 6. 
From the tough failure of the material with a holelike morphology, Fig. 6a, depending on the microstructure of the samples, there was a gradual increase in the proportion of fission failure, which showed mainly intercrystalline spreading and partly transcrystalline spreading.
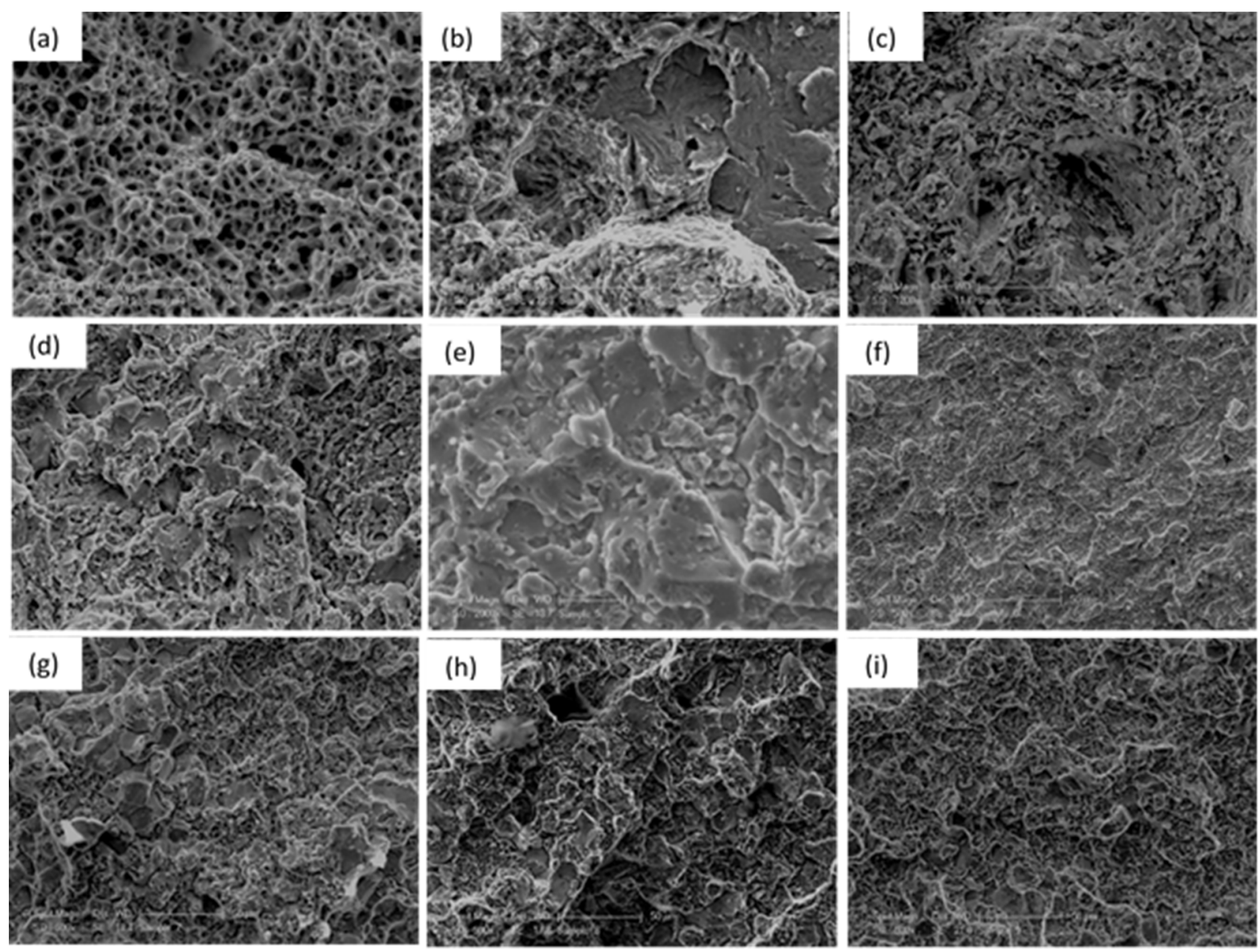

Fig. 6 Structure of fracture surfaces. (a) - initial structure, (b) - initial structure after hardening, (c) - initial structure after hardening and tempering, (d) - structure after long-term annealing, (e) - bardened structure after long-term annealing, (f) - tempered structure after bardening and long-term annealing, (g) - structure after boriding, (b) - hardening structure after hardening, (i) - tempered structure after hardening and long-term annealing

\section{Conclusion}

The results presented in this study show and prove the fact which is already known for a long time that due to boriding it is possible to increase the tribological abrasion resistance of the $100 \mathrm{Cr} 6$ steel structure and improve its mechanical properties such as tensile strength and hardness. . However, during powder boriding, a multiphase porous layer of $\mathrm{Fe}_{2} \mathrm{~B}-\mathrm{FeB}$ is formed. This layer does not have the same toughness and resistance to tribological abrasion as a singlephase diffusion layer of $\mathrm{Fe}_{2} \mathrm{~B}$. Therefore we need to look at other ways to further increase the wear resistance of the borided substrate. To form a singlephase diffusion layer of $\mathrm{Fe}_{2} \mathrm{~B}$ using boriding, we could shorten the time of the boriding process or reduce its temperature, or use a completely different boriding technology. Changing the powder boriding parameters could extend the time taken for the concentration of boron at the surface interface of the treated material to approach the value necessary for the formation of the structural phase of FeB. The second way to reduce this structural phase after boriding is by annealing. The concentration differences of boron in both structural phases would be gradually reduced, which would lead to the formation of a single-phase $\mathrm{Fe}_{2} \mathrm{~B}$ layer. Further experiments in this direction will build on this. They will deal with the reduction of the formation of a multiphase layer of borides on the surface of $100 \mathrm{Cr} 6$ steel by changing the parameters of the powder borid-ing process and using alternative boriding technologies and subsequent treatment of boriding diffusion layers using laser and plasma technologies. 


\section{Acknowledgments}

This study was supported by the project SGS2021-030 "Development of new materials, application of modern methods of their processing, ecological production, welding, and testing".

\section{References}

[1] Sedlak, J., Tropp, P., Chladil, J., Osicka, K. and SLIWKOVA, P. (2015). High-Speed Cutting of Bearing Rings from Material $100 \mathrm{Cr} 6$. Manufacturing Tecbnology, 15(5), pp.899-908.

[2] FABIAN, P. and ZRAK, A. (2016). Evaluation of Selected Properties of Steel 100Cr6 at Different Ways of Heat Treatment. Manufacturing Technology, 16(4), pp.687-691.

[3] KAWULOK, R., SCHINDLER, I., SOJKA, J., KAWULOK, P., OPĚLA, P., PINDOR, L., GRYCZ, E., RUSZ, S. AND ŠEVČÁK, V. (2020). Effect of Strain on Transformation Diagrams of 100Cr6 Steel. In: Crystals, 10(4), p.326

[4] Tran, X., Vu, T. and Dang, K. (2017). NUMERICAL SIMULATION OF THE HEAT TREATMENT PROCESS FOR 100Cr6 STEEL. Acta Metallurgica Slovaca, 23(3), pp.236-243.

[5] GERSTENBERGER, J. (2010). Vytváření tvrdých a otěruvzdorných povrchů pomocí boridování. In: MM Spektrum, Vol. 3

[6] ZIMMERMAN, C. (2013). Boriding (Boronizing) of Metals. In: Steel Heat Treating Fundamentals and Processes . pp.709-724

[7] ČSN EN ISO 6892-1. (2019). Metallic materials - Tensile testing -Part 1: Method of test at room temperature. Available at: http://www.technicke-normy-csn.cz/inc/nahled_normy.php?norma $=420310$-csn-en-iso6892-1\&kat $=510425$

[8] ASTM G99. (2016). Standard Test Method for Wear Testing with a Pin-on-Disk Apparatus.[online] Astm.org. Available at:https://www.astm.org/DATABASE.CART /HISTORICAL/G99-05R16.htm

[9] JECH, J. (1977). Tepelné zpracování oceli. Nakladatelství technické literatury. Praha

[10] MEHL, R. (2015). The Structure and Rate of Formation of Pearlite. Metallography, Microstructure, and Analysis, 4(5), pp.423-443

[11] KARTAL, G., TIMUR, S., SISTA, V., ERYILMAZ, O. AND ERDEMIR, A. (2011). The growth of single Fe2B phase on low carbon steel via phase homogenization in electrochemical boriding (PHEB). Surface and Coatings Technology, 206(7), pp.2005-2011

[12] USLU, I., COMERT, H., IPEK, M., CELEBI, F., OZDEMIR, O. AND BINDAL, C. (2007). A comparison of borides formed on AISI 1040 and AISI P20 steels. Materials \& Design, 28(6), pp.1819-1826.

[13] SKÁlOVÁ, J., KOUTSKÝ, J. AND MOTYČKA, V. (2000). Nauka o materiálech. Tiskové středisko ZČU. Plzeň. ISBN: 80-7082677-0

[14] KRAUS, V. (1999). Tepelné apracování a slinování. 2. vydání. Tiskové středisko ZČU, Plzeň. ISBN 80-708-2582-0 